\title{
DIOXINS AND HUMAN TOXICITY
}

\author{
Natalija MARINKOVIĆ ${ }^{1}$, Daria PAŠALIĆ ${ }^{1}$, Goran FERENČAK ${ }^{2}$, Branka GRŠKOVIĆ ${ }^{3}$, and \\ Ana STAVLJENIĆ RUKAVINA ${ }^{1}$
}

\begin{abstract}
Department of Chemistry and Biochemistry, Zagreb University School of Medicine ${ }^{1}$, Medikol Outpatient Clinic ${ }^{2}$, Forensic Science Centre "Ivan Vučetič", General Police Directorate, Ministry of Interior 3 , Zagreb, Croatia
\end{abstract}

Received in January 2010

Accepted in October 2010

\begin{abstract}
The term dioxins usually refers to polychlorinated dibenzo-dioxins (PCDDs) and polychlorinated dibenzofurans (PCDFs). As 2,3,7,8-tetrachloro-dibenzo-p-dioxin (TCDD) has the highest toxic potential, the toxic potentials of other PCDDs and PCDFs are defined in comparison with it. Human exposure to dioxins can be environmental (background), occupational, or accidental pollution. In the human body, dioxins are in part metabolised and eliminated, and the rest is stored in body fat. People vary in their capacity to eliminate TCDD, but it is also dose-dependent; the elimination rate is much faster at higher than lower levels. The liver microsomal P4501A1 enzyme oxygenates lipophilic chemicals such as dioxins. It is encoded by the CYP1A1 gene. Cytosolic aryl hydrocarbon receptor (AhR) mediates their carcinogenic action. It binds to dioxin, translocates to nucleus and together with hydrocarbon nuclear translocator (ARNT) and xenobiotic responsive element (XRE) increases the expression of CYP1A1.

Dioxins are classified as known human carcinogens, but they also cause noncancerous effects like atherosclerosis, hypertension, and diabetes. Long-term exposures to dioxins cause disruption of the nervous, immune, reproductive, and endocrine system. Short-term exposure to high levels impairs the liver function and causes chloracne. The most sensitive population to dioxin exposure are the foetuses and infants. A large number of health effects have been documented in the scientific literature, and they all place dioxins among the most toxic chemicals known to man.
\end{abstract}

KEY WORDS: aryl hydrocarbon receptor, CYP1A1, health effects, hydrocarbon nuclear translocator, liver, P4501A1, PCDDs, PCDFs TCDD

Dioxins are a group of chlorinated organic chemicals, and the term usually includes polychlorinated dibenzodioxins (PCDDs) and polychlorinated dibenzo-furans (PCDFs). Some of them have harmful characteristics depending on the number and structural position of chlorine atoms.

PCDDs and PCDFs are formed of two benzene rings bonded via oxygen atoms. In PCDDs, two rings are joined by two oxygen bridges and in PCDFs by a carbon bond and one oxygen bridge. Chlorine atoms can be attached to eight different places on the molecule, numbered from 1 to 8 (Figure 1). Of 210 dioxin and dibenzofuran congeners, only 17 are toxic. 2,3,7,8-tetrachlorodibenzo-p-dioxin $(2,3,7,8$-TCDD,
TCDD), a molecule with four chlorine atoms, is the best known and the most toxic dioxin (Figure 2) (1). It has the highest toxic potential (toxic equivalent factor), the toxic potentials of other 16 PCDDs and PCDFs are defined in comparison to it (2). Only 7 of 75 PCDDs and 10 out 135 PCDFs are determined in laboratories $(3,4)$.

Dioxins have no use. The only natural sources of dioxins are forest fires and volcano activities. Most are formed and released as by-products of human activities, especially of industrial processes and incomplete combustion processes like waste incineration. Other sources of dioxins in air include emissions from oilor coal-fired power plants, and burning of chlorinated 


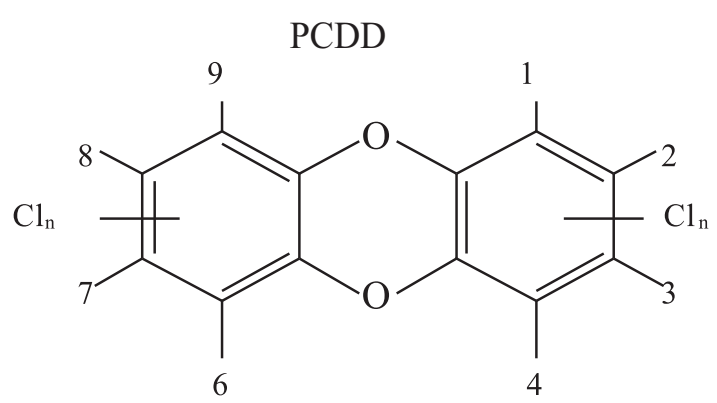

Figure 1 Chemical structure of $P C D D$ and $P C D F$<smiles>Clc1cc2c(cc1Cl)Oc1cc(Cl)c(Cl)cc1O2</smiles>

Figure 2 Chemical structure of 2,3,7,8-TCDD

compounds such as polychlorinated biphenyls (PCBs). They contaminate various chlorinated pesticides and herbicides. Dioxins are released in waste waters from pulp and paper mills which use chlorine or chlorinecontaining chemicals in the bleaching process (5). However, the main industrial emission sources of dioxins which contribute $45 \%$ of total emissions are waste incinerators, ferrous, and non-ferrous metal production and power generation, and heating while about $40 \%$ of the total emission is released by uncontrolled combustion processes (6).

In pure form, dioxins are colourless solids or crystals, but they enter the environment as mixtures containing a variety of individual components and impurities. Dioxins formed by combustion are bound to particles such as ash. Small particles can be transported to much longer distances from the emission source. Dioxins are hydrophobic and strongly lipophilic, and their solubility in organic solvents increases with chlorine content. As they are not soluble in water, in aquatic environment most of them attach strongly to any material with high organic content, especially to microscopic plants and animals (plankton) which are eaten by larger animals. This is how they circulate and accumulate at each step of the food chain. This process is called biomagnification.

Considering that dioxins are found in mixtures with other dioxins and structurally related compounds (PCBs), it is very difficult to calculate their toxicity. Toxic Equivalency Factor (TEF) of 2,3,7,8-TCDD is 1 . All other TEFs are expressed<smiles>Cc1c(I)c(I)c2c(oc3c(C)c(Cl)c(I)c(I)c32)c1I</smiles>

in relation to this reference, and show the relative toxicity of other dioxins. The toxic potency of a mixture is a sum of each compound's TEF, multiplied with its concentration. This value is known as Toxic Equivalent (TEQ) $(5,7)$.

Dioxins have raised a number of issues in relation to municipal solid waste, medical waste, and industrial incinerators. While incineration minimizes the quantity of waste and destroys some hazardous components within the waste, it also produces other harmful substances, including dioxins. The amount of dioxins produced during incineration depends on chamber temperature, $\mathrm{O}_{2}$ and $\mathrm{CO}_{2}$ concentrations, and especially on the chlorine content of waste. Temperatures from $200{ }^{\circ} \mathrm{C}$ to $400{ }^{\circ} \mathrm{C}$ favour PCDD formation, while temperatures over $800{ }^{\circ} \mathrm{C}$ destroy PCDDs (2). Pyrolysis, a process occurring in the absence of oxygen, at temperatures higher than $700{ }^{\circ} \mathrm{C}$ causes $99 \%$ destruction of all PCBs and dioxins. However, this is an expensive technology and is rarely used. Shibamoto et al. (8) showed that the same samples of waste incinerated at different temperatures yielded different TEQ values; low temperatures yielded higher TEQs than higher temperatures. However, recent technological advances and the use of filters have reduced the dioxin emissions $(9,10)$. Nevertheless, Zhu et al. (11) have estimated that dioxin emission is actually increasing because the sources of dioxin emission are also increasing without significant improvement in reduction technologies.

Data about dioxin emission at country levels or industry monitoring data in different countries are scarce. A study which included 51 countries and their national dioxin emission inventories showed that the TEQ of dioxins released into the environment from 2000 to 2007 was about $36 \mathrm{~kg}$ per year (6). In addition, it identified ferrous and non-ferrous metal production, power generation and heating and waste incineration as the main emission sources of dioxins, which contribute to $45 \%$ of total emissions, while about $40 \%$ is released by uncontrolled combustion. 


\section{HISTORY}

The $20^{\text {th }}$ century has seen a number of dioxinrelated accidents. One of the most notorious is the US Monsanto chemical company accident (12). The company manufactured industrial chemicals, PCBs, pesticides, herbicides, and other chemicals which contained high levels of dioxins and dioxinlike substances. In the 1930s, it was already evident that these substances posed serious health hazard to chemical workers, who developed skin rashes, chloracne (a long-lasting skin disease causing skin lesions), and a wide range of other symptoms (12, 13). Many products manufactured by Monsanto were contaminated with dioxins, including the widely used household disinfectant Lysol, and the known defoliant Agent Orange, used in the Vietnam War. Although Agent Orange was not produced exclusively by Monsanto Company, its products contained the highest levels of dioxins. Agent Orange was a herbicide and a defoliant used by the US army in the Vietnam War from 1961 to 1971 to destroy forest cover for the enemy and their food supplies. It was the most used herbicide within the US army programme. Estimations go as high as 72 million litres of herbicide sprayed over Vietnam, Cambodia, Thailand, and Laos. Severe consequences were seen in Vietnam veterans as a result of exposure to high levels of Agent Orange (14). There were numerous lawsuits in the US courts, which US veterans filed against companies which produced Agent Orange. The aggregate claim amount reached a total of 180 million \$, and many cases are still in courts.

Another accident occurred in the 1970s at Times Beach, Missouri, USA. Oil used for spraying streets for dust control had been highly contaminated with dioxins. When the contamination was discovered by the Environmental Protection Agency (EPA), the US government ordered the town to be evacuated and the area cleaned. During the process, more than 265,000 $t$ of dioxin-contaminated soil was incinerated and the waste ash buried on site. Today, that place is a state park commemorating the famous road Route $66(15,16)$.

In 1976, an explosion occurred in a 2,4,5trichlorophenol reactor of the ICMESA chemical plant in Seveso (25 km north from Milan), Italy. Several thousands of people were exposed to substantial quantities of 2,3,7,8-TCDD (17).

In 1999, a severe crisis emerged in Belgium when $500 \mathrm{t}$ of fodder was contaminated with $50 \mathrm{~kg}$ of PCBs and $1 \mathrm{~g}$ of dioxins, which were distributed to animal farms mostly in Belgium, but also in the Netherlands, France, and Germany. After a few months, the first signs of toxicity started to appear at chicken farms. Health crisis broke out in Belgium following toxicological analysis. Instantly, all poultry and derived products were removed from the market and most of them were destroyed (18). Health studies showed that the body burden was tripled in people exposed to contaminated food. However, no signs of acute health effects were reported (18).

The best known case was dioxin poisoning of the Ukrainian president Viktor Yushchenko in 2004 (19, 20). His blood serum level was $108,000 \mathrm{pg} \mathrm{g}^{-1}$ lipid weight, which is 50,000 times the level in general population. Viktor Yuschenko's TCDD levels were monitored using high-resolution mass spectrometry and gas chromatography at the Geneva University Hospital, Switzerland (21). Mr Yuschenko suffered severe health consequences and disfiguration of the face typical for the chloracne (19-21).

\section{EXPOSURE PATHWAYS}

Human exposure to dioxins can be environmental, occupational, or accidental pollution (as described above). General population is mostly exposed to background environmental levels. Most exposures involve secondary pathways such as food of animal origin or other products containing dioxins. According to the World Health Organization (WHO) (22), animal products such as meat, fish, and eggs are the major source of dioxin in humans (22). Exposure can also occur through inhalation, drinking water, soil ingestion, and skin absorption.

Once dioxins enter the human body, a part is metabolised and eliminated and the other part is stored in body fat (bioaccumulation). To be eliminated from the body, dioxins first have to convert to polar derivatives. Biological half-life differs between congeners; 2,3,7,8-TCDD half-life is between five and ten years (23), arguably seven to 11 years (24). Elimination depends on dose, age, and quantity of body fat. Aylward et al. (25) have shown a certain variability in individual capacity to eliminate TCDD; elimination was quicker in men and younger people than in women and older people. In addition, recent studies have shown dose-dependent elimination of TCDD; elimination rate was much greater with higher than with lower levels $(25,26)$.

WHO has set standards for the tolerable daily intake (TDI) of dioxins at TEQ $=(1$ to 4$) \mathrm{pg} \mathrm{kg}^{-1}$ body 
weight per day. At those exposures no toxic effects have been noticed (27). As dioxins accumulate in body fat, the total amount of dioxin uptake equals its body burden (average dioxin human tissue level at a given point in time) and TEQ can be expressed in $\mathrm{pg} \mathrm{kg}^{-1}$ of body weight or in $\mathrm{pg} \mathrm{g}^{-1}$ of serum lipid. The WHO reported that the standard TDI of TEQ $=(1$ to 4$) \mathrm{pg} \mathrm{kg}^{-1}$ body weight results in body burden of TEQ $=(2$ to 6$) \mathrm{ng} \mathrm{kg}^{-1}$ body weight or (10 to 30$) \mathrm{pg} \mathrm{g}^{-1}$ serum lipid. Table 1 compares body burdens of different exposures to dioxins (of people exposed to different amounts of dioxins) $(1,27)$.

\section{MOLECULAR MECHANISM OF DIOXIN ACTION}

Dioxins accumulated in the adipose tissue are expressed as body burden. They can be metabolised and eliminated by biochemical mechanisms such as enzyme complex of cytochrome P450. The cytochrome P450 superfamily plays a critical role in the oxygenation of xenobiotics (including drugs and environmental and occupational pollutants such as dioxins) $(28,29)$. Oxygenation is the first step in their conversion to polar substrates, which can be excreted from the body. The liver microsomal P450 enzymes involved in xenobiotic biotransformation belong to three main $\mathrm{P} 450$ gene families: CYP1, CYP2, and CYP3. P4501A1 (encoded by CYP1A1 gene) oxygenates lipophilic chemicals such as dioxins. Induction of P4501A1 is a result of increased transcription of the CYP1A1 gene (29). The most potent inducers of the CYP1A1 expression are indolo(2,3-b)carbazole (polycyclic aromatic hydrocarbon, PAH), and 2,3,7,8-TCDD $(29,30)$. It is known that CYP1A1 detoxifies carcinogens like
PAHs and related compounds, but can also bioactivate them into reactive toxic metabolites (31). However, $\mathrm{Hu}$ and Bunce (32) have shown that the metabolism of PCDDs, PCDFs, and PCBs represents detoxification prior to bioactivation.

Over the years, many studies have given an insight into the molecular mechanisms of CYP1A1 induction, especially into the transcription through aryl hydrocarbon receptor (AhR) action $(31,33,34)$.

$\mathrm{AhR}$ is a cytosolic receptor that binds to different environmental pollutants, including dioxins, and mediates their carcinogenic action $(31,33,34)$. It is a ligand-activated nuclear transcription factor which mediates cellular response in terms of expression regulation of a large number of genes. AhR upregulates a number of xenobiotic metabolising enzymes such as cytochrome P4501A1 (CYP1A1), P4501A2 (CYP1A2), and P4501B1 (CYP1B1) as well as the phase II enzymes, glutathione S-transferase A1 (GST-A1) and UDP-glucuronosyltransferases (UGT106) $(35,36)$. However, CYP1A1 is the most potently induced gene following AhR activation (31).

After TCDD exposure, AhR binds to a ligand, then translocates into the nucleus, where it forms an active heterodimer with aromatic hydrocarbon nuclear translocator (ARNT). This AhR/Arnt heterodimer binds to a specific xenobiotic responsive element (XRE) located upstream in the promoter region of the target gene, resulting in increased expression of the gene (37-39). A study which investigated the effects of PAHs and dioxins on 1152 genes in waste incineration workers occupationally exposed to dioxin reported upregulation of five genes involved in oxidative stress, including GSTA1 (40).

Activated AhR also interacts with other signalling proteins involved in the regulation of the cell cycle and apoptosis. It can alter cell function such as growth and differentiation. In addition, dioxins can induce

Table 1 Body burden at different dioxin exposures $(1,27)$

\begin{tabular}{|c|c|c|}
\hline & & $\begin{array}{c}\text { Body burden (average human tissue levels of dioxins) } \\
\text { I-TEQ / } \mathrm{pg} \mathrm{kg}^{-1} \text { b.w. }\end{array}$ \\
\hline \multicolumn{2}{|l|}{ TDI } & 2,000 to 6,000 \\
\hline \multicolumn{2}{|c|}{$\begin{array}{l}\text { Industrialized countries (background } \\
\text { exposure) }\end{array}$} & 2,000 to 6,000 \\
\hline \multirow{2}{*}{$\begin{array}{l}\text { Cases of acute } \\
\text { dioxin poisoning }\end{array}$} & $\begin{array}{l}\text { Seveso chemical } \\
\text { factory workers }\end{array}$ & 20,000 to 100,000 \\
\hline & US Vietnam veterans & 10,000 \\
\hline
\end{tabular}

$T D I=$ tolerable daily intake $\left[T E Q=(1\right.$ to 4$) \mathrm{pg} \mathrm{kg}^{-1}$ b.w.]

$I-T E Q=$ international toxic equivalent 
responses caused by other signalling pathways (41). Although AhR signalling is the first step of dioxin toxicity, there can be a variety of biochemical and toxicological responses to dioxin exposure. However, Poellinger (42) has allowed that there may also be an AhR-independent pathway of dioxin-induced toxicity.

\section{HEALTH EFFECTS}

Humans are not equally exposed to dioxins or equally sensitive to dioxin exposure. Developing foetuses and newborn babies are the most sensitive group, especially those exposed to high levels of dioxins through mothers' milk. Some people are exposed to higher amounts of dioxins than the TDI because of their specific dietary habits (large seafood consumers like the Inuit) or occupation (workers in pesticide industry or incinerators of hazardous waste).

Short-term exposure to high levels of dioxins is known to damage liver function and cause chloracne, a chronic inflammatory skin condition characterised by keratinous plugs with cysts and dark acnes. They mostly appear on the face, but in case of severe poisoning also on shoulders, back, chest, and the abdomen (21).

Long-term exposure is associated with disturbances in the nervous, immune, reproductive, and endocrine system. TCDD's persistence in the body can cause atherosclerosis, hypertension, diabetes, and nervous system damage (43). The International Agency for Research on Cancer (IARC) and the WHO classified TCDD as a "known human carcinogen", based on many human and animal epidemiology data (44).

After the Seveso incident, many scientific activities and investigations were performed, especially those concerning the health effects of acute exposure to dioxins. Bertazzi et al. (45) reported that Seveso population had increased incidence of the gastrointestinal, lymphatic, and hematopoietic cancer and of the soft-tissue sarcoma. A number of studies were conducted 10 to 20 years after the accident (45-47). Their aim was to biomonitor the affected population and track their cancer and noncancer mortality. They all found increased death rate from all cancer types, especially in the male population. Moreover, a significant increase in lymphohaemopoietic neoplasms was found in both sexes, as well as in non-Hodgkin's lymphoma (NHL) and myeloid leukaemia. Mortality due to diabetes mellitus was substantial in women, while chronic circulatory and respiratory diseases were slightly higher than in general population $(46,47)$.

Over the last few decades waste incinerators have been the subject of great controversies. Many studies have evaluated there effects on populations living in their vicinity (48-53). Most studies assess the health impact of dioxins. Zambon et al. (48) found a significant association between the sarcoma risk in general population and dioxin emissions from incinerators and industrial plants. A Portuguese study (49) showed statistically significant differences in PCDD and PCDF blood levels between exposed and non-exposed individuals. A French study (50) of non-Hodgin's lymphoma (NHL) patients in the 1990s showed a statistical association between living in the vicinity of incinerators and increased risk of NHL. Nadal et al. (51) compared their 2007 with 1998 and 2002 results of PCDDs and PCDFs levels in adipose tissue in people living near a hazardous waste incinerator in Catalonia, Spain. They found a $64 \%$ drop from 1998 to 2007, but also a $47 \%$ increase between 2002 and 2007, which was not directly connected to emissions from the incineration facility. These findings were supported by two studies of dioxin exposure with human milk and plasma as bioindicators $(52,53)$. The results also show that plasma and milk levels of dioxins are much better indicators of current exposure. Through the years, dioxins tend to accumulate in the adipose tissue and can not reliably show the extent of current exposure, especially in older people, because the body burden increases with age.

Direct inhalation seems to be a minor contributor of dioxin exposure in comparison with other sources, especially with food (54-56). This may also be related to significant technological advancement of incineration facilities in emission treatment systems and maintenance (57).

There is a number of studies of health effects in populations occupationally exposed to much higher levels of dioxins than typical for background exposure of the general population (58-60). A German retrospective cohort study included 1189 male workers in an herbicide plant in Hamburg occupationally exposed to TCDD, PCDDs, and PCDFs (58). It established that cancer and ischemic heart disease mortality were in a dose-dependent relationship with TCDD, PCDD, and PCDF levels; workers exposed to the highest levels of PCDDs and PCDFs ran the 
highest risk of cancer development and ischemic heart disease. Ott and Zober (59) evaluated long-term effects in workers accidentally exposed to high levels of dioxins. They found a dose-dependent relationship between TCDD and gastrointestinal carcinoma, as well as increase in total cancer mortality. An international cohort study of workers exposed to phenoxy herbicides, chlorophenols, and dioxins in 12 countries reported a small increase in overall cancer and in the risk for specific cancers (soft-tissue sarcoma, malignant neoplasms, non-Hodgkin's lymphoma, and lung cancer) (60).

Some epidemiological studies investigated the relationship between dioxin exposure and breast cancer risk (61-63). A study which included women from Seveso found a significantly increased risk of breast cancer associated with increased TCDD in serum (61). A study from Russia reported higher risk of breast cancer among women living in the area of a chemical plant which contaminated the surrounding environment with dioxins (62). However, Viel et al. (63) did not find an association between breast cancer risk in younger women and exposure to dioxins emitted from a local incinerator. Moreover, the study showed a decreased risk in older women who lived in the area, which was highly polluted with dioxins.

Not only is TCDD carcinogenic, but it is also toxic for the development, endocrinological, immunological, and reproductive system in experimental animals (64-66). Gestational exposure to TCDD produces foetotoxic responses in most laboratory mammals such as decreased foetal growth, prenatal mortality, nervous system changes (67).

Increased metabolism in pregnant women and mobilisation of accumulated dioxins in fat tissue present a threat to foetuses and infants. Dioxins can pass through the placenta and reach the foetus and exposure continues in infants through breastfeeding. Brouwer et al. (68) suggest that prenatal exposure could be even more relevant than postnatal exposure. The WHO reports that breastfeeding accounts for $10 \%$ to $12 \%$ of lifetime human exposure (69). Kreuzer et al. (70) reported higher levels of TCDD in breastfed compared to non-breastfed infants. However, TCDD body burden decreases a few years after the breastfeeding has stopped and is no different from the levels found in non-breastfed children. For these and many other reasons breast feeding remains recommended by the WHO.

\section{CONCLUSION}

Many accidents related to dioxin overexposure occurred in the last century. They have shown us how toxic and dangerous dioxins really are. There is evidence that problems with high emissions of dioxins in incineration processes are being taken care of. Moreover, WHO reports a decrease in environmental concentrations and a decline in general population's exposure to PCDDs and PCDFs (27). However, many countries have not introduced dioxin monitoring into routine practice, mainly because technology is expensive.

Studies assessing the threat to populations exposed to high dioxin levels in their living or working environment were relevant for establishing reference values for dioxins such as TDI. Today, research has focused on toxicogenomics and changes in gene expression, which provides answers about genetic variations and individual differences in susceptibility to dioxin and other toxins.

A large number of health effects have been documented in research literature and even though many are still inconsistent, they all agree that dioxins are among the most toxic chemicals known to man. These studies have certainly helped us to understand the importance of proper hazardous substances management and the need to minimize their release in the environment at all times to protect human health.

\section{REFERENCES}

1. GreenFacts, Facts on health and the environment. Scientific facts on dioxins 2004 [displayed 12 November 2010]. Available from http://www.greenfacts.org/en/dioxins/index. htm

2. McKay M. Dioxin characterization, formation and minimization during municipal solid waste (MSW) incineration: review. Chem Eng J 2002;86:343-68.

3. Behnisch PA, Hosoe K, Sakai S. Combinatorial bio/chemical analysis of dioxin and dioxin-like compounds in waste recycling, food/feed, humans/wildlife and the environment. Environ Int 2001;27:495-519.

4. Alcock RA, Behnisch PA, Jones KC, Hagenmaier H. Dioxinlike PCBs in the environment-human exposure and the significance of sources. Chemosphere 1998;37:1457-72.

5. GreenFacts, Facts on health and the environment. Scientic facts on Dioxins 2004. Level 2- Details on dioxins [displayed 12 November 2010]. Available at http://www.greenfacts. org/en/dioxins/dioxins-greenfacts-level2.pdf.

6. Ren Z, Zheng M. Impact of human activities on dioxins emissions at national scale. Chemosphere 2009;76:853-9.

7. Kulkarni P, Crespo J, Afonso C. Dioxins sources and current remediation technologies - A review. Environ Int 2008;34:139-53. 
8. Shibamoto T, Yasuhara A, Katami T. Dioxin formation from waste incineration. Rev Environ Contam Toxicol 2007;190:141.

9. Inoue K, Yasuda K, Kawamoto K. Report: Atmospheric pollutants discharged from municipal solid waste incineration and gasification-melting facilities in Japan. Waste Manag Res 2009;27:617-22.

10. Ni Y, Zhang H, Fan S, Zhang X, Zhang Q, Chen J. Emissions of $\mathrm{PCDD} / \mathrm{Fs}$ from municipal solid waste incinerators in China. Chemosphere 2009;75:1153-8.

11. Zhu J, Hirai Y, Sakai S, Zheng M. Potential source and emission analysis of polychlorinated dibenzo-p-dioxins and polychlorinated dibenzofurans in China. Chemosphere 2008;73(Suppl 1):S72-7.

12. Institute of Medicine (U.S.). Committee to Review the Health Effects in Vietnam Veterans of Exposure to Herbicides. Other Health Effects In: Veterans and Agent Orange: health effects of herbicides used in Vietnam. National Academies Press; 1994. p. 672-708.

13. Commoner B. The political history of dioxins. Synthesis/ Regeneration 7-8, 1995 [displayed 12 November 2010]. Available at http://www.greens.org/s-r/078/07-03.html.

14. Le TN, Johansson A. Impact of chemical warfare with agent orange on women's reproductive lives in Vietnam: a pilot study. Reprod Health Matters 2001;18:156-64.

15. Environmental Protection Agency (EPA). Times Beach Site, Missouri [displayed 12 November 2010]. Available at http:/ www.epa.gov/region07/cleanup/npl_files/mod980685226. pdf.

16. Leistner M. The Times Beach Story. Synthesis/Regeneration 7-8, 1995 [displayed 12 November 2010]. Available at http://www.greens.org/s-r/078/07-09.html.

17. De Marchi B, Funtowicz S, Ravetz J. Seveso: A paradoxical classic disaster. In: Mitchell JK, editor. The long road to recovery: Community response to industrial disasters. Tokyo: United Nations University Press; 1996.

18. Larabeke N, Hens L, Schepens P, Covaci A, Baeyens J, Everaert K, Bernheim J, Vlietinck R, Poorters G. The Belgian PCB and dioxin incident of January-June 1999: exposure data and potential impact on health. Environ Health Perspect 2001;109:265-73.

19. Chivers CJ. A Dinner in Ukraine Made for Agatha Christie. New York Times 2004.

20. Sterling B, Hanke W. Dioxin toxicity and chloracne in the Ukraine. J Drugs Dermatol 2005;4:148-50.

21. Sorg O, Zennegg M, Schmid P, Fedosvuk R, Valikhnovskyi R, Gaide O, Kniazevych V, Saurat JH. 2,3,7,8 tetrachlorodibenzo-p-dioxin (TCDD) poisoning in Victor Yushchenko: identification and measurement of TCDD metabolites. Lancet 2009;374:1179-85.

22. World Health Organization (WHO). Dioxins and their effects on human health [displayed 12 November 2010]. Available at http://www.who.int/mediacentre/factsheets/fs225/en/index. html.

23. Olson, J. R. Pharmacokinetics of dioxin and related chemicals. In Dioxins and Health. A. Schecter, ed. New York, NY: Plenum Press; 1994. p. 163-167.

24. Pirkle JL, Wolfe WH, Patterso DG, Needham LL, Michalek JE, Miner JC, Peterson MR, Phillips DL. Estimates of the half-life of 2,3,7,8-tetrachlorodibenzo-p-dioxin in Vietnam veterans of Operation Ranch Hand. J Toxicol Environ Health 1989;27:165-71.
25. Aylward LL, Brunet RC, Carrier G, Hays SM, Cushing CA, Needham LL, Patterson DG, Gerthoux PM, Brambilla P, Mocarelli P. Concentration-dependent TCDD elimination kinetics in humans: toxicokinetic modeling for moderately to highly exposed adults from Seveso, Italy, and Vienna, Austria, and impact on dose estimates for the NIOSH cohort. J Expo Anal Environ Epidemiol 2005;15:51-65.

26. Emond C, Michalek JE, Birnbaum L, Devito MJ. Comparison of the use of a physiologically based pharmacokinetic model and a classical pharmacokinetic model for dioxin exposure assessments. Environ Health Perspect 2005;113:1666-8.

27. World Health Organization (WHO). Executive summary. Assessment of health risks of dioxins: re-evaluation of the Tolerable daily intake (TDI). Geneva: WHO; 1998.

28. Ma Q. Induction of CYP1A1. The AhR/DRE paradigm: Transcription, receptor regulation, and expanding biological roles. Curr Drug Metab 2001;2:149-64.

29. Whitlock JP. Induction of cytochrome P4501A1. Annu Rev Pharmacol Toxicol 1999;39:103-25.

30. Fujii-Kuriyama Y, Mimura J. Molecular mechanisms of AhR functions in the regulation of cytochrome P450 genes. Biochem Biophys Res Commun 2005;338:311-7.

31. Barouki R, Coumoul X, Fernandez-Salguero P. The aryl hydrocarbon receptor, more than a xenobiotic-interacting protein. FEBS Lett 2007;581:3608-15.

32. Hu K, Bunce NJ. Metabolism of polychlorinated dibenzo-pdioxins and related dioxin-like compounds. J Toxicol Environ Health B Crit Rev 1999;2:183-210.

33. Hoffman EC, Reyes H, Chu FF, Sander F, Conley LH, Brooks BA, Hankinson O. Cloning of a factor required for activity of the Ah (dioxin) receptor. Science 1991;252:954-8.

34. Okino ST, Whitlock JP. The aromatic hydrocarbon receptor, transcription, and endocrine aspects of dioxin action. Vitam Horm 2000;59:241-64.

35. Walisser JA, Glover E, Pande K, Liss AL, Bradfield CA. Aryl hydrocarbon receptor-dependent liver development and hepatotoxicity are mediated by different cell types. Proc Natl Acad Sci USA 2005;102:17858-63.

36. Yueh MF, Huang YH, Hiller A, Chen S, nguyen N, Tukey $\mathrm{RH}$. Involvement of the xenobiotic response element (XRE) in Ah receptor-mediated induction of human UDPglucuronosyltransferase 1A. J Biol Chem 2003;278:15001-6.

37. Mimura J, Fujii-Kuriyama Y. Functional role of AhR in the expression of toxic effects by TCDD. Biochim Biophys Acta 2003;1619:263-8.

38. Puga A, Barnes S, Dalton TP, Chang C, Knudsen ES, Maier MA. Aromatic hydrocarbon receptor interaction with the retinoblastoma protein potentiates repression of E2Fdependent transcription and cell cycle arrest. J Biol Chem 2000;275:2943-50.

39. Mandal PK. Dioxin: a review of its environmental effects and its aryl hydrocarbon receptor biology. J Comp Physiol B 2005; 175:221-30.

40. Kim MK, Oh S, Lee JH, Im H, Ryu YM, Oh E, Lee J, Lee E, Sul D. Evaluation of biological monitoring markers using genomic and proteomic analysis for automobile emission inspectors and waste incinerating workers exposed to polycyclic aromatic hydrocarbons or 2,3,7,8,-tetracholrodedibenzo-p-dioxins. Exp Mol Med 2004;36:396-410.

41. Puga A, Tomlinson CR, Xia Y. Ah receptor signals cross-talk with multiple developmental pathways. Biochem Pharmacol 2005;69:199-207. 
42. Poellinger L. Mechanistic aspects - the dioxin (aryl hydrocarbon) receptor. Food Addit Contam 2000;17:2616.

43. Pelclová D, Urban P, Preiss J, Lukás E, Fenclová Z, Navrátil T, Dubská Z, Senholdová Z. Adverse health effects in humans exposed to 2,3,7,8-tetrachlorodibenzo-p-dioxin (TCDD). Rev Environ Health 2006;21:119-38.

44. International Agency for Research on Cancer (IARC). Polychlorinated dibenzo-para-dioxins and polychlorinated dibenzofurans. IARC monographs on the evaluation of carcinogenic risks to humans, Volume 69. Geneva: IARC; 1997.

45. Bertazzi PA, Bernucci I, Brambilla G, Consonni D, Pesatori A. The Seveso studies on early and long-term effects of dioxin exposure: a review. Environ Health Perspect 1998;106(Suppl 2):625-33.

46. Bertazzi PA, Zocchetti C, Guercilena S, Consonni D, Tironi A, Landi MT, Pesatori AC. Dioxin exposure and cancer risk: a 15-year mortality study after the "Seveso accident". Epidemiology 1997;8:646-52.

47. Bertazzi PA, Consonni D, Bachetti S, Rubagotti M, Baccarelli A, Zocchetti C, Pesatori AC. Health effects of dioxin exposure: a 20-year mortality study. Am J Epidemiol 2001;153:1031-44.

48. Zambon P, Ricci P, Bovo E, Casula A, Gattolin M, Fiore AR, Chiosi F, Guzzinati S. Sarcoma risk and dioxin emissions from incinerators and industrial plants: a population-based case-control study (Italy). Environ Health 2007;16:6-19.

49. Reis MF, Miguel JP, Sampaio C, Aguiar P, Melim JM, Päpke $O$. Determinants of dioxins and furans in blood of nonoccupationally exposed populations living near Portuguese solid waste incinerators. Chemosphere 2007;67:S224-30.

50. Viel JF, Daniau C, Goria S, Fabre P, de Crouy-Chanel P, Sauleau EA, Empereur-Bissonnet P. Risk for non Hodgkin's lymphoma in the vicinity of French municipal solid waste incinerators. Environ Health 2008;7:51.

51. Nadal M, Domingo JL, García F, Schuhmacher M. Levels of PCDD/F in adipose tissue on non-occupationally exposed subjects living near a hazardous waste incinerator in Catalonia, Spain. Chemosphere 2009;74:1471-6.

52. Schuhmacher M, Kiviranta H, Ruokojärvi $\mathrm{P}$, Nadal M, Domingo JL. Concentrations of PCDD/Fs, PCBs and PBDEs in breast milk of women from Catalonia, Spain: a follow-up study. Environ Int 2009;35:607-13.

53. Nadal M, Perelló G, Schuhmacher M, Cid J, Domingo JL. Concentrations of PCDD/PCDFs in plasma of subjects living in the vicinity of a hazardous waste incinerator: follow-up and modeling validation. Chemosphere 2008;73:901-6.

54. Schuhmacher M, Domingo JL. Long-term study of environmental levels of dioxins and furans in the vicinity of a municipal solid waste incinerator. Environ Int 2006;32:397404.

55. Huang HY, Jeng TY, Lin YC, Ma YC, Kuo CP, Sung FC. Serum dioxin levels in residents living in the vicinity of municipal waste incinerators in Taiwan. Inhal Toxicol 2007;19:399-403.

56. Domingo JL, Agramunt MC, Nadal M, Schuhmacher M, Corbella J. Health risk assessment of PCDD/PCDF exposure for the population living in the vicinity of a municipal waste incinerator. Arch Environ Contam Toxicol 2002;43:461-5.

57. Lee SJ, Choi SD, Jin GZ, Oh JE, Chang YS, Shin SK. Assessment of PCDD/F risk after implementation of emission reduction at a MSWI. Chemosphere 2007;68:856-63.
58. Flesch-Janys D, Berger J, Gurn P, Manz A, Nagel S, Waltsgott H, Dwyer JH. Exposure to polychlorinated dioxins and furans $(\mathrm{PCDD} / \mathrm{F})$ and mortality in a cohort of workers from a herbicide-producing plant in Hamburg, Federal Republic of Germany. Am J Epidemiol 1995;142:1165-75.

59. Ott MG, Zober A. Cause specific mortality and cancer incidence among employees exposed to 2,3,7,8-TCDD after a 1953 reactor accident. Occup Environ Med 1996;53:60612.

60. Kogevinas M, Becher H, Benn T, Bertazzi PA, Boffetta P, BuenoDe-Mesquita HB, Coggon D, Colin D, Flesch-Janys D, Fingerhut M, Green L, Kauppinen T, Littorin M, Lynge E, Mathews JD, Neuberger M, Pearce N, Saracci R. Cancer mortality in workers exposed to phenoxy herbicides, chlorophenols, and dioxins. An expanded and updated international cohort study. Am J Epidemiol 1997;145:1061-75.

61. Warner M, Eskenazi B, Mocarelli P, Gerthoux PM, Samuels S, Needham L, Patterson D, Brambilla P. Serum dioxin concentrations and breast cancer risk in the Seveso Women's Health Study. Environ Health Perspect 2002;110:625-8.

62. Revich B, Aksel E, Ushakova T, Ivanova I, Zhuchenko N, Klyuev N, Brodsky B, Sotskov Y. Dioxin exposure and public health in Chapaevsk, Russia. Chemosphere 2001;43:951-66.

63. Viel JF, Clément MC, Hägi M, Grandjean S, Challier B, Danzon A. Dioxin emissions from a municipal solid waste incinerator and risk of invasive breast cancer: a populationbased case-control study with GIS-derived exposure. Int J Health Geogr 2008;7:4.

64. Birnbaum LS, Tuomisto J. Non-carcinogenic effects of TCDD in animals. Food Addit Contam 2000;17:275-88.

65. Luebke RW, Chen DH, Dietert R, Yang Y, King M, Luster MI. Immunotoxicology Workgroup. The comparative immunotoxicity of five selected compounds following developmental or adult exposure. J Toxicol Environ Health B Crit Rev 2006;9:1-26.

66. US Environmental Protection Agency (US EPA). Exposure and Human Health Reassessment of 2,3,7,8-Tetrachlorodibenzo$p$-Dioxin (TCDD) and Related Compounds. Part III: Integrated Summary and Risk Characterization for 2,3,7,8-Tetrachlorodibenzo- $p$-Dioxin (TCDD) and Related Compounds Washington DC: US Environmental Protection Agency; 2000. p. 264.

67. Nishijo M, Kuriwaki J, Hori E, Tawara K, Nakagawa $\mathrm{H}$, Nishijo $\mathrm{H}$. Effects of maternal exposure to 2,3,7,8tetrachlorodibenzo-p-dioxin on fetal brain growth and motor and behavioral development in offspring rats. Toxicol Lett 2007; 173:41-7.

68. Brouwer A, Ahlborg UG, Van den Berg M, Birnbaum LS, Boersma ER, Bosveld B, Denison MS, Earl Gray L, Hagmar L, Holene E, Huisman M, Jacobson SW, Jacobson JL, Koopman-Esseboom C, Koppe JG, Kulig BM, Morse DC, Muckle G, Peterson RE, Sauer PJJ, Seegal RF, SmitsVan Prooije AE, Touwen BCL, Weisglas-Kuperus N, Winneke G. Functional aspects of developmental toxicity of polyhalogenated aromatic hydrocarbons in experimental animals and human infants. Eur J Pharmacol 1995;293:140.

69. World Health Organization (WHO). Hazardous chemicals: main risks to children's health. Fact Sheet EURO/02/04. Copenhagen: WHO; 2004.

70. Kreuzer PE, Csanady GA, Baur C, Kessler W, Papke O, Greim H, Filser JG. 2,3,7,8-Tetrachlorodibenzo- p-dioxin (TCDD) and congeners in infants. A toxicokinetic model of human lifetime body burden by TCDD with special emphasis on its uptake by nutrition. Arch Toxicol 1997;71:383-400. 


\section{Sažetak}

\section{DIOKSINI I NJIHOVA TOKSIČNOST ZA LJUDE}

Dioksini su skupina kemijskih spojeva koji obuhvaćaju poliklorirane dibenzo-dioksine (PCDD) i poliklorirane dibenzo-furane (PCDF). Najveći toksični potencijal (faktor ekvivalentne toksičnosti) ima 2,3,7,8-TCDD, dok su toksični potencijali drugih PCDD i PCDF određeni u odnosu na njega. Izloženost dioksinima može biti izravna: izloženost dioksinima emitiranim u okoliš kao posljedica nesreće, profesionalna izloženost te neizravna, tzv. pozadinska. Nakon ulaska u ljudski organizam dioksini se djelomično metaboliziraju i eliminiraju, a ostatak se pohranjuje u adipozno tkivo. Postoji određena varijabilnost između ljudi u kapacitetu eliminacije TCDD. Eliminacija TCDD ovisna je o dozi - kod veće izloženosti (izloženost višim koncentracijama) brzina eliminacije je viša nego kod manje izloženosti (izloženost nižim koncentracijama). Enzim P4501A1 najvažniji je u oksigenaciji lipofilnih supstrata poput dioksina. Kodiran je genom CYP1A1.

AhR je stanični receptor koji djeluje kao transkripcijski faktor koji posreduje u njihovu karcinogenom učinku. AhR veže dioksin te se premješta u jezgru gdje zajedno s ARNT (engl. aryl hydrocarbon nuclear translocator) i XRE (engl. xenobiotic responsive element), smještenim u promotorskoj regiji gena za CYP1A1, uzrokuje povećani izražaj CYP1A1.

Dioksini su karcinogeni spojevi, ali imaju i nekarcinogene učinke poput ateroskleroze, hipertenzije, dijabetesa, poremećaj živčanog, imunosnog, reproduktivnog i endokrinog sustava, posebice kod kronične izloženosti. Akutna izloženost uzrokuje oštećenja jetre i klorakne. Najosjetljivija skupina izloženosti dioksinu je dojenčad u prenatalnom i postnatalnom razdoblju. U znanstvenoj i stručnoj literaturi dokumentirani su brojni zdravstveni učinci kao posljedice izloženosti dioksinima te ih svi ističu kao jedne od najtoksičnijih kemijskih spojeva.

KLJUČNE RIJEČI: $A R N T, C Y P 1 A 1$, jetra, P4501A1, $P C D D, P C D F$, receptor arilnih ugljikovodika, TCDD, zdravstveni učinci

\section{CORRESPONDING AUTHOR:}

Natalija Marinković

Department of Chemistry and Biochemistry

Zagreb University School of Medicine

Šalata 3, 10000 Zagreb, Croatia

E-mail:nmarinko@snz.hr 